\title{
Эрбиевый волоконный лазер с пассивной синхронизацией мод и частотой повторения импульсов 150 МГц
}

\author{
$\underline{\text { А.Д. Зверев }}^{1,2, *}$, В.А. Камынин ${ }^{2}$ С.А. Филатова ${ }^{2}$, Ю.Г. Гладуш ${ }^{3}$, А.Г. Насибулин ${ }^{3,4}$ \\ Б.И. Денкер ${ }^{2}$, Б.И. Галаган ${ }^{2}$, С.Е. Сверчков ${ }^{2}$, В.Б. Цветков ${ }^{2}$, С.Л. Семёнов \\ ${ }^{1}$ МГУ имени М.В. Ломоносова Россия \\ ${ }^{2}$ Институт общей физики имени А.М. Прохорова Российской академии наук, Россия \\ ${ }^{3}$ Сколковский институт науки и технологий, Россия \\ ${ }^{4}$ Университет Аалто, Финляндия \\ ${ }^{5}$ Институт общей физики им. А.М. Прохорова Российской академии наук, Научный \\ иентр волоконной оптики им. Е.М. Дианова, Россия \\ *E-mail: izverevad@gmail.com
}

DOI: 10.31868/RFL2020.79-80

Лазерные источники ультракоротких импульсов находят своё применение в различных областях науки и техники. Они могут использоваться для создания источников суперконтинуума [1], терагерцового излучения [2], также их применяют в микроскопии [3], обработке материалов и т.д. В последние годы интересной задачей в исследованиях стала генерация ультракоротких импульсов с субгигагерцовой частотой повторения. Стандартные активные волокна и волоконные компоненты не позволяют получить основную частоту следование импульсов существенно выше 100 МГц. Для решения этой задачи, как правило, используются волоконные лазеры, работающие в режиме гармонической синхронизации мод, в которых используются специальные компоненты, такие как: микрорезонаторы, совмещенные каплер-изоляторы или специальные активные волокна с высокой концентрацией активной примеси.

В представленной работе исследован лазер с линейным резонатором на основе композитного эрбиевого волокна (рис. 1), работающий в режиме пассивной синхронизации мод. Для реализации синхронизации мод использовались синтезированные в аэрозоле одностенные углеродные нанотрубки (SWCNTs [4]), которые наносились между фольгой и ферулами.

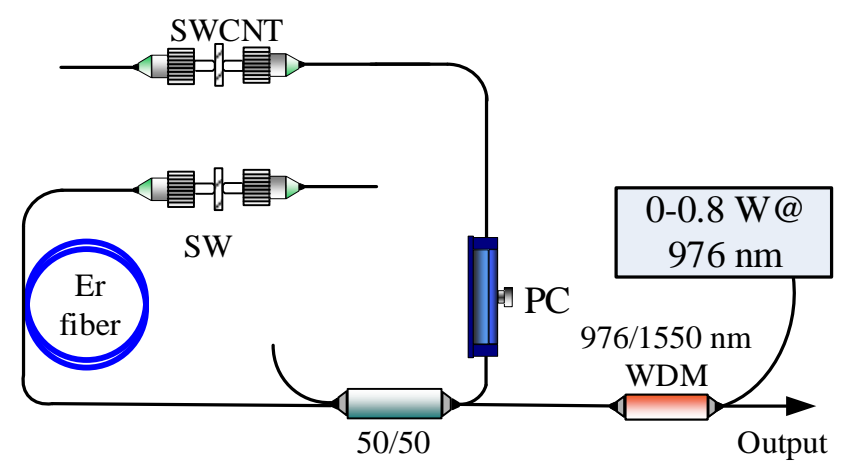

Рис. 1. Схема волоконного эрбиевого лазера. SWCNT - соединённые ферулы, между которыми находятся нанотрубки (SWCNTs) и алюминиевая фольга. SW - соединённые ферулы, между которыми находится алюминиевая фольга. PC - контроллер поляризации.

После достижения уровня накачки 740 мВт, наблюдалась стабильная генерация с частотой повторения импульсов 150 МГц. Временные и спектральные характеристики выходного излучения показаны на рис. 2(a), а на рис. 2(b) изображен его радиочастотный спектр. 
a)

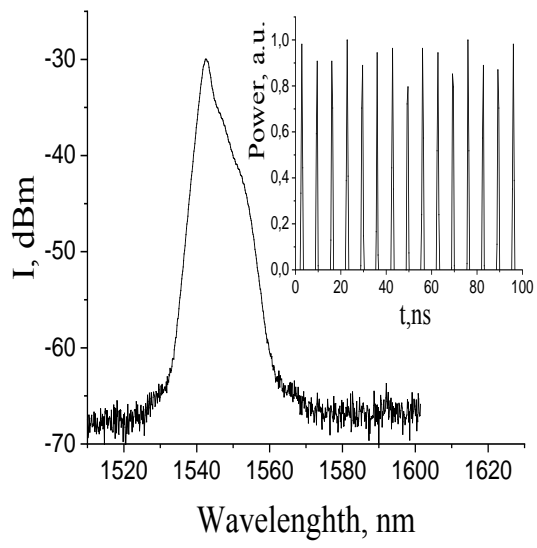

b)

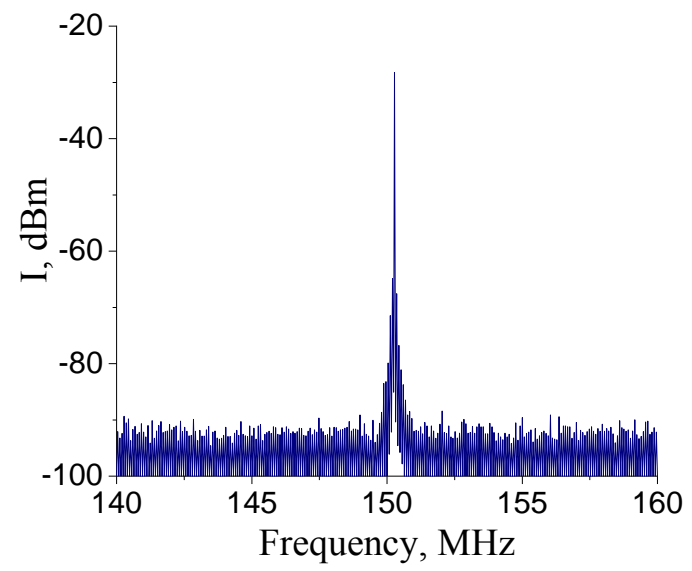

Рис. 2. (a) Временные и спектральные характеристики выходного излучения. (b) Радиочастотный спектр.

Длительность импульса составляла 0,5 пс. Средняя выходная мощность составила 9,2 мВт.

\section{Литература}

[1] G. Sobon, M. Klimczak et al, Opt. Mater. Express 4, 7-15 (2014).

[2] Lohner, A., P. Kruck, and W. W. Rühle, Applied Physics B, 59.2, 211-213 (1994).

[3] E.O. Potma, D.J. Jones et al, Opt. Lett. 27, 1168 (2002).

[4] Kaskela, Antti, et al., Nano letters 10.11, 4349-4355 (2010). 